Journal of Social Sciences (COES\&RJ-JSS)

ISSN (E): 2305-9249 ISSN (P): 2305-9494

Publisher: Centre of Excellence for Scientific \& Research Journalism, COES\&RJ LLC

Online Publication Date: $1^{\text {st }}$ January 2019

Online Issue: Volume 8, Number 1, January 2019

https://doi.org/10.25255/jss.2019.8.1.24.40

\title{
A Theoretical Study on the Impact of Strategic Orientation on Organizational Performance: Examining the Mediating Role of Learning Culture in Jordanian Telecommunication Companies
}

\author{
Najwa Asha'al \\ Department of Business Management, School of Business, The University of Jordan, \\ Amman, Jordan \\ Bader Obeidat \\ Department of Business Management, School of Business, The University of Jordan, \\ Amman, Jordan, b.obeidat@ju.edu.jo \\ Hazar Alhmoud \\ Department of Management Information Systems, School of Business, The University of \\ Jordan, Amman, Jordan, h.hmoud@ju.edu.jo
}

Abstract:

This study proposed a research model to investigate the impact of strategic orientation on organizational performance in Jordanian telecommunications companies. In addition, it will examine the mediating role of learning culture using the dimensions of the learning organization questionnaire (DLOQ). A model was developed that presents the dimensions of strategic orientation, learning culture, and organizational performance. A random sample of 321 managerial and non-managerial employees will be taken. We will test if strategic orientations (market, technology, entrepreneurial) have a significant positive impact on organizational performance. Also, will test if the learning culture, in terms of promoting inquiry and dialogue, collaboration and team learning, empowering people towards a collective vision, connecting the organization to its environment, and strategic leadership have a significant positive impact on organizational performance or not. Furthermore, the findings could reveal that learning culture mediates the impact of strategic orientation and organizational performance. Based on the research hypotheses, we will examine if Jordanian telecommunication companies should be aware of the importance of strategic orientations on improving organizational performance. Also, will test if Jordanian telecommunication companies must ensure that learning culture has a vital role in improving organizational performance or not.

Keywords:

Strategic Orientation, Learning Culture, Organizational Performance, Jordan

\section{Citation:}

Asha'al Najwa; Obeidat, Bader; Hmoud Hazar Y.; (2019); A Theoretical Study on the Impact of Strategic Orientation on Organizational Performance: Examining the Mediating Role of Learning Culture in Jordanian Telecommunication Companies; Journal of Social Sciences (COES\&RJ-JSS), Vol.8, No.1, pp:24-40; https://doi.org/10.25255/jss.2019.8.1.24.40. 


\section{Introduction}

Nowadays, globalization, severe competition, government regulations, increasing customer demands, and substitute services put huge pressures on firms. Accordingly, firms try to have new philosophies that determine the plans, decision-making framework, the nature and scope of their activities, which ensure the growth and sustainability of the firm. While it is difficult to achieve strategic competitiveness in such complex and turbulent markets, firms use different techniques and styles to achieve the right level of competitive advantage in their pursuit to alleviate such difficulties, which compound and accumulate, while not allowing them to formulate a clear and deep understanding of what affects performance. The core of any strategic orientation is to achieve the right level of performance returns that allows firms to be competitive and to survive over time (Altindag et al., 2011; Al-dalahmeh et al., 2018; Masa'deh et al., 2018). A firm's strategy influences its structure, investment, activity, relations with the market, and performance. Al-Ansaari et al. (2015) stated that firms can utilize their strategies as a way to create new capabilities and solve problems, while a strategy could provide the framework to help the firm and its managers to deploy required assets, identify new opportunities for providing customers with acceptable products and services, and deliver and sell such products or services in the marketplace with higher profits through strategic orientation. Strategic orientation is a concept that is intensively used in the research fields of strategic management, entrepreneurship, and marketing (Bing and Zhengping, 2011). The strategic orientation of a firm reflects the strategic directions applied to make the appropriate behaviors for the sustainability and the superior performance of its business (Chahal et al., 2016).

Indeed, the firm's competitive landscape is continuously changing, which is forcing them to change, learn, and adapt, in order to survive and grow. To promote better agility to the organization's needs and changing environment, organizations must be designed so that learning is embedded. This requires learning to be at all levels of the organization, such as the individual level, team level, organizational learning, and global level (Bhaskar and Mishra, 2017).Learning culture could be characterized as a culture that creates, integrates, and disseminates knowledge, in addition to modifying itself and transforming its action based on new knowledge, experience, and perceptions to achieve its strategic objectives (Dekoulou and Trivellas, 2015). In order to create superior performance outcomes, Marsick and Watkins (2003) stated that organizations could create a learning culture by creating continuous learning opportunities, promoting inquiry and dialogue, encouraging collaboration and team learning, creating systems to capture and share learning, empowering people towards a collective vision, connecting the organization to its environment, and having strategic leaders to support learning (Kim et al., 2017).

Organizational performance is the end result of activities that include the actual outcomes of the strategic management process (Wheelen et al., 2017, p. 55). Tomal and Jones (2015) stated that organizational performance is the actual outputs or results of a firm as measured against that firm's intended outputs. Different studies used many criteria to determine the performance. According to Zehir et al. (2015), performance could be measured by financial and non-financial (operational) indicators. Financial measurements are related to economic indicators, such as profitability and sales growth 
(e.g. the return on investment, the return on sales, and the return on equity) and nonfinancial measurements are related to the operational success indicators, such as market share, new product development, quality, satisfaction, and market effectiveness. Nonfinancial performance measurements focus on a firm's long-term success, such as internal business process efficiency, company image, innovation, customer satisfaction, customer loyalty, employee satisfaction, and employee turnover (Avci et al., 2011).

\section{Literature Review}

This research was conducted to propose a study to examine the impact of strategic orientation on organizational performance mediated by learning culture in Jordanian telecommunication companies, where this sector is highly competitive and important.

\subsection{The Relationship between Strategic Orientation and Organizational Performance} Many studies investigated the relationship between strategic orientation and organizational performance with different dimensions of each previous variable, for instance, Altindag et al. (2011) conducted a study to examine the effect of strategic orientation on the performance of Turkish family-owned firms, and the findings revealed a positive relationship between strategic orientation and the qualitative and quantitative performance of family firms. In addition, Chahal et al. (2016) examined the synergistic impact of marketing orientation and strategic orientation on business performance on nine hundred small- and medium-sized enterprises in Jammu District, North India, and they found that both orientations have a positive impact on small- and medium-sized enterprises' performance.

Moreover, Al-Ansaari et al. (2015) examined the role of strategic orientation in driving small- and medium-sized enterprises in the UAE (Dubai) context to better perform, the findings revealed that market orientation has a positive effect on business performance compared to technology and alliance orientations within small- and medium-sized enterprises in the Dubai marketplace. Sarker and Palit (2015) identify whether there is any relationship between strategic orientation and the performance of small- and medium-sized enterprises operating in Bangladesh, and the results show that they are statistically significant with small- and medium-sized enterprises performance. Furthermore, Gupta and Gupta (2015) tried to understand the longitudinal relationship between entrepreneurial orientation and firm performance by studying analyses indicating that EO has a strong initial effect on firm performance.

Brower and Rowe (2017) tried to address two questions with respect to firm corporate social performance (CSP): 'Do different strategic orientations have differential impacts on a firm's overall CSP?'; and, if so, 'is there an effect of a firm's strategic orientation on the types of CSP that firm implements?' Using a unique data set that combines the survey data on organizations' strategic orientations for 115 US organizations, they empirically examined the impact on the corporate social performance levels of four different organization strategic orientations, which are: customer, competitor, shareholder, and interfunctional coordination. Their empirical analysis showed that organizations with a stronger orientation towards customers have higher levels of corporate social performance overall, and when organizations have a stronger customer orientation, they 
also found that the organization has higher corporate social performance levels in domains that were dedicated towards secondary stakeholders, while organizations with a stronger shareholder orientation showed higher levels of corporate social performance were dedicated towards primary stakeholders.

In addition, Aragón and Sánchez (2005) analyzed strategic orientation, performance and management characteristics for a sample of 1,351 Spanish small- and medium-sized enterprises (SMEs), and they found that strategic orientation was an influential element of SMEs' management and determined performance. Moreover, Jansson et al. (2017) examined the relationship between two common strategic orientations: entrepreneurial orientation (EO) and market orientation (MO), in relation to a commitment to sustainability and its practices, and management values in SMEs. In this study's analysis of 450 Swedish SMEs, questionnaire responses confirmed the influence of MO, EO, and sustainability practices on a commitment to sustainability. The findings here were twofold, showing that firms committed to sustainability for both the market and entrepreneurial advantages of sustainability. The results also noted that different parts of $\mathrm{MO}$ and $\mathrm{EO}$ had varying levels of importance for SMEs commitment to sustainability.

Franczak et al. (2009), explored the relationship between strategic orientation and the performance of $21 \mathrm{SMEs} .857$ respondents were surveyed. After the data were analyzed, the findings showed there to be a positive relationship between strategic orientation and performance of SMEs. Moreover, Eris et al. (2012) studied the influence of innovation, market orientation, and learning orientation on performance in the Turkish logistics sector. Data for the study was collected from 102 respondents and analyzed using structural equation modeling; the research findings revealed that the firms in the logistics sector in Turkey are innovative, market oriented, and learning oriented, and that all the study variables were effective and had an impact on performance enhancement.

In addition, Theodosiou et al. (2012) conducted a study to examine the influence of strategic orientation alternatives on organizational performance with the mediating effect of marketing capabilities. The study also examined how environmental forces and organizational characteristics influence the decision to pursue lucrative strategic orientations. Data was collected from 316 bank branch managers and the subsequent analysis showed that competition intensity, decentralization in decision making, and market turbulence play a pivotal role in setting the priorities of managerial strategy. Competitor orientation and innovation orientation were also found to play a significant role in developing marketing capabilities, which would then have a positive impact on organization performance.

\subsection{The Relationship between Learning Culture and Organizational Performance}

Learning culture can be described as an organizational culture that is oriented towards the promotion and facilitation of workers' learning, its sharing and dissemination, in order to contribute to organizational development and performance. Malik and Garg (2017) stated that learning culture represents an organization's effort to create learning opportunities for all its members. Moreover, Kim et al. (2017) examined the impact of a learning organization on knowledge and financial performance as measured by the 
DLOQ, with the results suggesting that a learning organization positively affects knowledge performance, which positively and strongly affects financial performance. On the other hand, Bhaskar and Mishra (2017) studied the validity of the concept of learning organization through the use of the Dimensions of Learning Organization Questionnaire (DLOQ) in an Indian public-sector organization, and revealed that the sample organization scores high on the various learning organization dimensions (seven dimensions of DLOQ), which in turn impact knowledge performance and financial performance.

Moreover, Bai and Fallah (2012) explored the relationship between organizational learning culture and organizational performance with a study from the perspective of Ministry of Sports and Youthsports experts in the Islamic Republic of Iran. The findings showed that there is significant positive correlation between organizational learning culture and organizational performance in sports experts from the Ministry of Sports and Youth.

Wahda (2017), studied the effect of organizational learning culture on organizational performance with a mediating effect of knowledge management, and the findings showed that organizational learning culture has the biggest effect on achieving organizational performance. Similar results were found in the Yu and Chen (2012) study, which chose Taiwan's University and College Libraries to study the relationship between organizational learning culture and organizational performance. The population for this study included all university and college libraries in Taiwan, and the main findings of the study showed that, regarding perceived value of organizational learning culture between university and college library staff in Taiwan, the dimension of 'promoting inquiry and dialogue' is at the top, followed by the dimensions of 'providing strategic leadership for learning', 'connecting the organization to its environment', 'encouraging collaboration and team learning', 'empowering people towards a collective vision', 'creating system to capture and share learning', and 'creating continuous learning opportunity'. Whereas the three organizational cultural dimensions of 'creating continuous learning opportunity', 'creating system to capture and share learning', and 'providing strategic leadership for learning' have a significantly positive effect on organizational knowledge performance, the three dimensions of 'creating continuous learning opportunity', 'create system to capture and share learning', and 'providing strategic leadership for learning' have a significantly positive effect on organizational extrinsic performance.

\subsection{The Relationship between Strategic Orientation and Learning Culture}

Most studies discussed each dimension of strategic orientation separate with learning culture. For instance, Onyema (2014) studied the effects of entrepreneurial orientation on organizational learning in a manufacturing firm in Nigeria. The result of the study indicated that entrepreneurial orientation has positive and significant impact on organizational learning. Meanwhile, Slater and Narver (1995) found that marketing orientation has a key role to play in the creation of a learning organization. In addition, Santos et al. (2005) discussed the relationship between market orientation and organizational learning culture, with the results stating that market-oriented firms can develop patterns of behavior and a system of values that allow them to offer greater 
value to the market in a sustained way, and, subsequently, create organizational learning culture.

Stephen et al. (2017) suggested a conceptual linkage between the dimensions of knowledge strategy and strategic orientation as a way of enhancing organizations' competitive performance. The dimensions of knowledge strategy have been discussed from perspectives, which direct organizational managers' attention to put it as a strategic resource to the organization, to help them to link it with the strategic activities of the organization, and perceive it as being vital to the immediate and future directions of the organization; they found that strategic orientation was used as a way of improving the organization's competitive performance, as well as a way to motivate knowledge-based competitive performance in the organization.

\subsection{The Mediating Role of Learning Culture on the Impact of Strategic Orientation on Organizational Performance}

Some previous studies investigated the relationship between strategic orientation on organizational performance (Al-Ansaari et al., 2015; Altindag et al., 2011), while other investigated the relationship between learning culture and organizational performance (Bhaskar and Mishra, 2017; Choi, 2015). According to the researchers' knowledge, there are insufficient studies investigating learning culture as a mediating factor between strategic orientation and organizational performance. The mediating effect of learning culture, according to researchers' opinions, will enhance organizational performance in telecommunication companies, so this study addresses this gap by developing and testing an integrated model that considers learning culture as an important mediator, thereby investigating the impact of strategic orientation on organizational performance by examining the mediating role of learning culture in Jordanian telecommunication companies.

\section{Research Methodology}

The goal of the research is to prose a research model in order to examine the impact of Strategic Orientation on Organizational Performance examining the Mediating Role of Learning Culture in Jordanian Telecommunication Companies. Primary data will be collected from the questionnaire, which was constructed based on the research model developed from the related literature, as follows: strategic orientation (Mu et al., 2011; Al-Ansaari et al., 2015), learning culture (Song et al., 2009), and organizational performance (Tseng and Lee, 2014). The questionnaire will use a Likert-type scale with five scale categories: (1 strongly disagree, 2 Disagree, 3 Neutral, 4 Agree, 5 strongly Agree). The questions will be divided into four sections representing: demographic variables, strategic orientation, learning culture, and organizational performance. Tables below show the variables measurement. 
A Theoretical Study on the Impact of Strategic Orientation .....

\subsection{Strategic orientation (The Independent Variable)}

Table 1. Strategic Orientation Measurement

\begin{tabular}{|c|c|}
\hline \multicolumn{2}{|r|}{ Strategic Orientation } \\
\hline Dimensions & Items \\
\hline \multirow[t]{6}{*}{ Market Orientation } & $\begin{array}{l}\text { Our business objectives are driven primarily by customer } \\
\text { satisfaction }\end{array}$ \\
\hline & $\begin{array}{l}\text { We constantly monitor our level of commitment and } \\
\text { orientation to serve customers' needs }\end{array}$ \\
\hline & $\begin{array}{l}\text { Our strategy for competitive advantage is based on our } \\
\text { understanding of customers' needs }\end{array}$ \\
\hline & $\begin{array}{l}\text { Our business strategies are driven by our beliefs about how } \\
\text { we can create greater value for customers }\end{array}$ \\
\hline & $\begin{array}{l}\text { We measure customer satisfaction systematically and } \\
\text { frequently }\end{array}$ \\
\hline & We give close attention to after-sales service \\
\hline \multirow[t]{4}{*}{ Technology Orientation } & $\begin{array}{l}\text { Our company technical innovation based on research results } \\
\text { is readily accepted }\end{array}$ \\
\hline & The company Management actively seeks innovative ideas \\
\hline & $\begin{array}{l}\text { Our company allocates resources for investments in latest } \\
\text { technologies and future forecasted technological changes }\end{array}$ \\
\hline & $\begin{array}{l}\text { In our company People are encouraged to have new ideas for } \\
\text { new services }\end{array}$ \\
\hline \multirow{5}{*}{$\begin{array}{l}\text { Entrepreneurial } \\
\text { Orientation }\end{array}$} & We have built capacity to react to market changes \\
\hline & We protect our advantages from industry changes \\
\hline & We prepare for radical industry changes \\
\hline & $\begin{array}{l}\text { We believed that wide-ranging acts were necessary to } \\
\text { achieve objectives }\end{array}$ \\
\hline & We initiated actions to which other organizations respond \\
\hline
\end{tabular}

\subsection{Learning culture (The Mediating Variable)}

Table 2. Learning Culture Measurement

\begin{tabular}{|c|c|}
\hline \multicolumn{2}{|r|}{ Learning Culture } \\
\hline Dimensions & Items \\
\hline \multirow[t]{3}{*}{ Continuous Learning } & We help each other to learn \\
\hline & We take time to support learning \\
\hline & We being rewarded for learning \\
\hline \multirow{3}{*}{$\begin{array}{l}\text { Promoting Inquiry and } \\
\text { Dialogue }\end{array}$} & We provide open feedback \\
\hline & We ask what others think \\
\hline & We spend time building trust \\
\hline \multirow{3}{*}{$\begin{array}{l}\text { Collaboration and Team } \\
\text { Learning }\end{array}$} & We have freedom to adapt goals \\
\hline & We revise thinking with information \\
\hline & We act on our recommendations \\
\hline
\end{tabular}


Journal of Social Sciences (COES\&RJ-JSS), 8(1), pp.24-40

\begin{tabular}{|l|l|}
\hline \multirow{2}{*}{$\begin{array}{l}\text { Creating Systems to Capture } \\
\text { and Share Learning }\end{array}$} & Our company creates measurement system \\
\cline { 2 - 2 } & Our company makes the lessons learned available \\
\cline { 2 - 2 } $\begin{array}{l}\text { Empowering People toward } \\
\text { a Collective Vision }\end{array}$ & Our company measures the results of training \\
\cline { 2 - 2 } & Our company recognize for taking initiative \\
\cline { 2 - 2 } $\begin{array}{l}\text { Connecting the Organization } \\
\text { to its Environment }\end{array}$ & Our company supports calculated risk-taking \\
\cline { 2 - 2 } & Our company encourage global perspectives \\
\cline { 2 - 2 } & Our company work with outside/resources \\
\hline Strategic Leadership & Our company encourage diverse perspectives \\
\cline { 2 - 2 } & Our company provides mentoring/coaching \\
\cline { 2 - 2 } & Our company provides opportunities to learn \\
\cline { 2 - 2 } & Our company ensures the consistent actions \\
\hline
\end{tabular}

\subsection{Organizational Performance (The Dependent Variable)}

Table 3. Non-Financial Performance Measurement

\begin{tabular}{|l|}
\hline \multicolumn{1}{|c|}{ Non - financial performance (Operational performance) } \\
\hline Dimensions \\
\hline Our company is able to grasp the right timing for launching new services \\
\hline Our company is equipped with the ability to develop high-quality new services \\
\hline The launch speed of new services is faster than other companies in the same industry \\
\hline $\begin{array}{l}\text { The degree of automation operation is much higher than other companies in the same } \\
\text { industry }\end{array}$ \\
\hline $\begin{array}{l}\text { Our company is able to adjust or change our management process based on the market } \\
\text { competition }\end{array}$ \\
\hline Our company is able to retain outstanding staff \\
\hline Our company is active in nurturing staff's leadership \\
\hline Our company puts high value on our staff's satisfaction on our corporate measures \\
\hline Our company has an excellent staff welfare policy \\
\hline Our company possesses comprehensive plans for our Future \\
\hline Our company vigorously invests in the development of new markets \\
\hline
\end{tabular}

\section{Research Model and Hypotheses Formulation}

The following hypotheses were developed:

First Main Hypothesis

$\mathrm{HO}_{1}$ : There is no statistically significant impact of strategic orientation on organizational performance at a significant level of $\alpha \leq 0.05$.

Sub-Hypotheses of the First Main Hypothesis:

$\mathrm{HO}_{1.1}$ : There is no statistically significant impact of market orientation on organizational performance at a significant level of $\alpha \leq 0.05$.

$\mathrm{HO}_{1.2}$ : There is no statistically significant impact of technology orientation on organizational performance at a significant level of $\alpha \leq 0.05$. 
$\mathrm{HO}_{1.3}$ : There is no statistically significant impact of entrepreneurial orientation on organizational performance at a significant level of $\alpha \leq 0.05$.

Second Main Hypothesis

$\mathrm{HO}_{2}$ : There is no statistically significant impact of strategic orientation on learning culture at a significant level of $\alpha \leq 0.05$.

Sub-Hypotheses of the Second Main Hypothesis:

$\mathrm{HO}_{2.1}$ : There is no statistically significant impact of market orientation on learning culture at a significant level of $\alpha \leq 0.05$.

$\mathrm{HO}_{2.2}$ : There is no statistically significant impact of technology orientation on learning culture at a significant level of $\alpha \leq 0.05$.

$\mathrm{HO}_{2.3}$ : There is no statistically significant impact of entrepreneurial orientation on learning culture at a significant level of $\alpha \leq 0.05$.

Third Main Hypothesis

$\mathrm{HO}_{3}$ : There is no statistically significant impact of learning culture on organizational performance at a significant level of $\alpha \leq 0.05$.

Sub-Hypotheses of the Third Main Hypothesis:

$\mathrm{HO}_{3.1}$ : There is no statistically significant impact of continuous learning on organizational performance at a significant level of $\alpha \leq 0.05$.

$\mathrm{HO}_{3.2}$ : There is no statistically significant impact of promoting inquiry and dialogue on organizational performance at a significant level of $\alpha \leq 0.05$.

$\mathrm{HO}_{3.3}$ : There is no statistically significant impact of collaboration and team learning on organizational performance at a significant level of $\alpha \leq 0.05$.

$\mathrm{HO}_{3.4}$ : There is no statistically significant impact of creating systems to capture and share learning on organizational performance at a significant level of $\alpha \leq 0.05$.

$\mathrm{HO}_{3.5}$ : There is no statistically significant impact of empowering people toward a collective vision on organizational performance at a significant level of $\alpha \leq 0.05$.

$\mathrm{HO}_{3.6}$ : There is no statistically significant impact of connecting the organization to its environment on organizational performance at a significant level of $\alpha \leq 0.05$.

$\mathrm{HO}_{3.7}$ : There is no statistically significant impact of strategic leadership on organizational performance at a significant level of $\alpha \leq 0.05$.

Fourth Main Hypothesis

$\mathrm{HO}_{4}$ : There is no statistically significant mediating role of learning culture on the impact of strategic orientation on organizational performance at a significant level of $\alpha \leq 0.05$. 


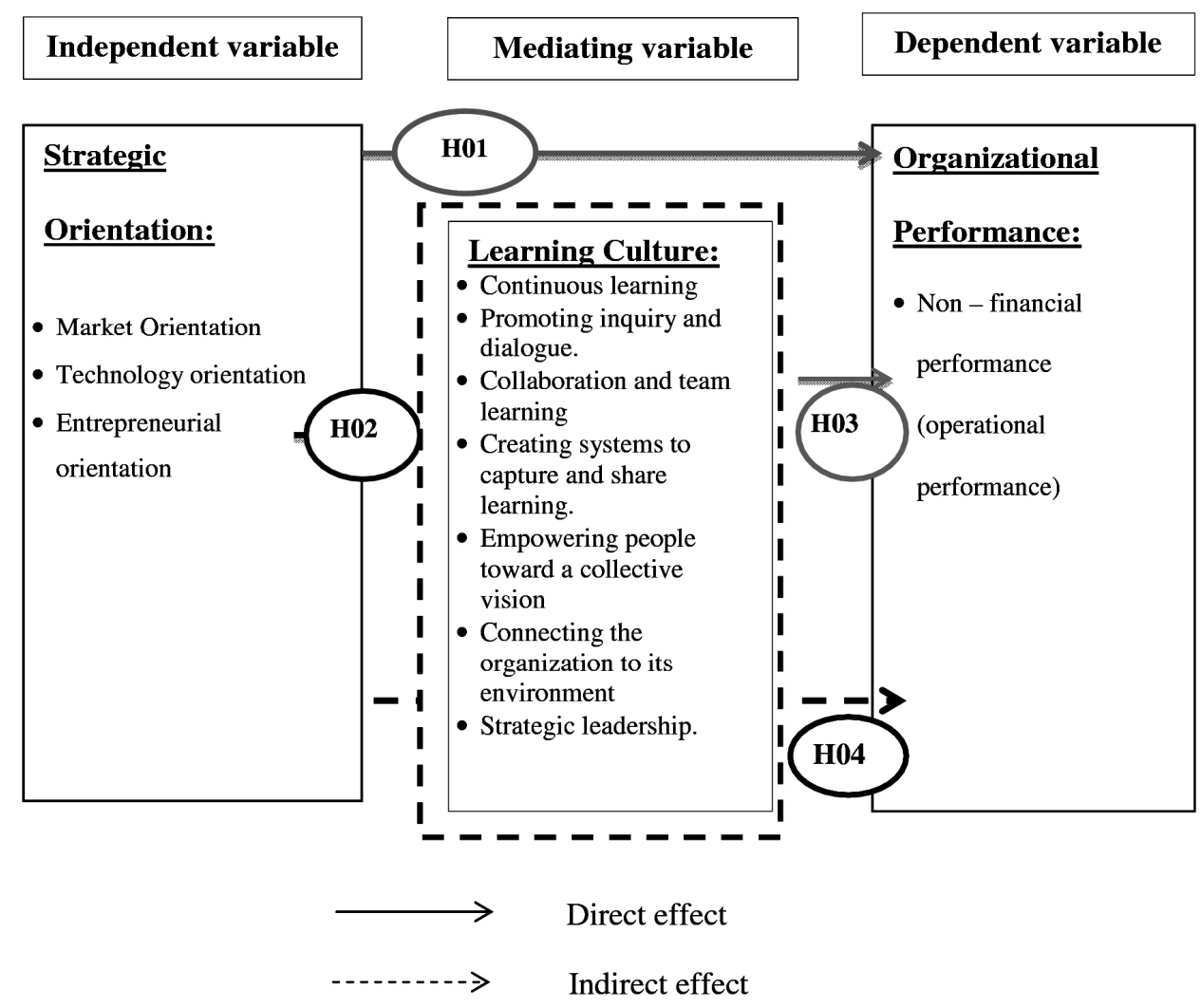

\section{Figure 1: Research model}

The research model is developed by the researcher based on the related literature as follows: Strategic orientation based on (Mu et al., 2011; Al-Ansaari et al., 2015), learning culture based on (Song et al., 2009), and organizational performance based on (Tseng and Lee, 2014).

\section{Data Analysis Techniques}

The population of this study will consider the three telecommunication companies in Amman (Zain, Orange, and Umniah), which consist of 2211 employees of all managerial and non-managerial positions.

Table 4. Number of Employees at each Company

\begin{tabular}{|l|c|c|c|}
\hline Company name & Zain & Umniah & Orange \\
\hline Number of employees & 1012 & 654 & 545 \\
\hline
\end{tabular}

The population of this study will be consisted of 2211 employees. According to Sekaran and Bougie (2013), the sample size for this population must be 318 employees. To arrive 
at this size, a paper questionnaire will be distributed to employees in various branches of the three companies, in addition to an electronic questionnaire that will be sending by email and to Linkedln accounts. The data collection through the questionnaire will be distributed to Zain, Orange, and Umniah employees, and then will be analyzed using Statistical Package for Social Sciences (SPSS). The percentages and frequencies will be used to describe the demographic profile of the respondents. In addition, in the descriptive statistics, the mean and the standard deviation will be used to describe the attitude of the respondents towards the variables, dimensions, and items of the study. A multi co-linearity test will also be conducted to make sure that there was no correlation between the independent variables of the study. Finally, multiple regression analysis will be used to test the hypotheses. In addition, Baron and Kenny's (1986) mediation model and Sobel's (1982) test will be used to test the mediation hypothesis.

\section{Conclusion}

The current research aimed to propose a model in order to investigate the impact of strategic orientation on organizational performance, examining the mediating role of learning culture in Jordanian telecommunication companies. Based on the literature review, the research model was developed, and will be examining the mediating role of learning culture on the relationship. Then, the data required for this study will be collected from 321 randomly sampled employees in three Jordanian telecommunication companies, Zain, Orange, and Umniah, through a paper questionnaire that will be distributed to the employees in various branches of the three companies, in addition to an electronic questionnaire that will be sent by email and to Linkedln accounts. Also, results based on specific analyses will be presented. All four of the main null hypotheses will be tested.

Also, researchers called for more research on the enabling factors of applying electronic services (e.g. Masa'deh, et al., 2008, 2013a, 2013b; Karajeh \& Maqableh, 2014; Maqableh \& Karajeh, 2014; Al-Dmour et al., 2015; Almajali \& Maqableh, 2015; Kateb et al., 2015; Maqableh et al., 2015; Kattoua et al., 2016; Masa'deh, 2016; Ammari et al., 2017; Tarhini et al., 2015; 2016, 2017a, 2017b; Almajali \& Al-Dmour, 2016; Almajali et al., 2016; Alenezi et al., 2017; Aldmour et al., 2017; Khwaldeh et al., 2017; Mikkawi \& Al-Lozi, 2017; Obeidat et al., 2017a, b; Yassien \& Mufleh, 2017; Tarhini et al., 2018; Al-Dmour et al., 2019), hence, future research is vital to examine these enablers as to assist stakeholders on their decisions on reaching high levels of such services, and in turn enhancing organizational performance in an optimal way.

We hope that the premise behind the coming results is that the telecommunication industry is considered to be one of the most knowledge-intensive industries, and it is believed to be a highly innovative and rapid growth sector. All these environmental changes put pressure on Jordanian telecommunication companies to improve services over time, in order to compete and survive. Accordingly, having a clear strategic orientation will enable Jordanian telecommunication companies to focus on conserving scarce resources, and paves the way for it to create the proper behaviors for the continuous superior performance, thereby consolidating strong competitive positions, growth, and sustainability. On the other hand, building a learning culture by creating 
continuous learning opportunities, promoting inquiry and dialogue, encouraging collaboration and team learning, creating systems to capture and share learning, empowering people towards a collective vision, connecting the organization to its environment, and having strategic leaders to support learning will help telecommunication companies to modify themselves and transform action based on new knowledge, experience, and perceptions, in order to achieve strategic objectives, thereby improving operational performance by focusing on long-term success, such as internal business process efficiency, company image, innovation, customer satisfaction, customer loyalty, employee satisfaction, and employee turnover, in order to achieve a competitive advantage, sustainability, and superior performance.

\section{References}

Al-Ansaari, Y., Bederr, H., \& Chen, C. (2015). Strategic Orientation and Business Performance: An Empirical Study in the UAE Context. Management Decision, 53(10), 2287-2302.

Al-dalahmeh, M., Khalaf, R., \& Obeidat, B. (2018). The Effect of Employee Engagement on Organizational Performance via the Mediating Role of Job Satisfaction: The Case of IT Employees in Jordanian Banking Sector. Modern Applied Science, 12(6), 17-43.

Al-Dmour, R., Al Haj Dawood, E., Al-Dmour, H., \& Masa'deh, R. (2019). The effect of customer lifestyle patterns on the use of mobile banking applications in Jordan. Int. J. Electronic Marketing and Retailing, Forthcoming.

Aldmour, R., Masa'deh, R., \& Obeidat, B. (2017). Factors influencing the adoption and implementation of HRIS applications: Are they similar. International Journal of Business Innovation and Research, 14(2), 139-167.

Al-Dmour, R, Obeidat, B., \& Almajali, D. (2015). The practice of HRIS applications in business organizations in Jordan: An empirical study. 4th Scientific \& Research Conference on New Trends in Business, Management and Social Sciences (COES\&RJTK15/1).

Alenezi, H., Tarhini, A., Alalwan, A., \& Al-Qirim, N. (2017). Factors affecting the adoption of e-government in Kuwait: A qualitative study. Electronic Journal of e-Government, 15(2), 84-102.

Almajali, D., \& Al-Dmour, R. (2016). The role of information technology in motivating students to accept e-learning adoption in universities: A case study in Jordanian universities. Journal of Business \& Management (COES\&RJ-JBM), 4(1), 36-46.

Almajali, D., \& Maqableh, M. (2015). Assessing the digital divide status of the Jordanian telecentre. International Journal of Communications, Network and System Sciences, 8(11), 428-439. 
Almajali, D., Masa'deh, R., \& Al-Lozi, M. (2016). Determinants of the actual use of elearning systems: An empirical study on Zarqa University in Jordan. Journal of Social Sciences (COES\&RJ-JSS), 5(2), 172-200.

Altindag, E., Zehir, C., \& Acar, A.Z. (2011). Strategic Orientations and their Effects on Firm Performance in Turkish Family Owned Firms. Eurasian Business Review, 1(1), 18-36.

Ammari, G., Alkurdi, B., \& Alshurideh, M. (2017). Investigating the impact of communication satisfaction on organizational commitment: a practical approach to increase employees' loyalty. International Journal of Marketing Studies, 9(2), 113-133.

Aragón Sánchez, A., \& Sánchez Marín, G. (2005). Strategic Orientation, Management Characteristics, and Performance: A Study of Spanish SMEs. Journal of Small Business Management, 43(3), 287-308.

Avci, U., Madanoglu, M., \& Okumus, F. (2011). Strategic Orientation and Performance of Tourism Firms: Evidence from a Developing Country. Tourism Management, 32(1), 147157.

Bai, N., \& Fallah, Z. (2012). Relationship between Learning Culture and Organizational Performance in Iran's Ministry of Sports and Youth.European Journal of Experimental Biology, 2(6), 2206-2211.

Baron, R.M.,\& Kenny, D. (1986). The Moderator-Mediator Variable Distinction in Social Psychological Research: Conceptual, Strategic, and Statistical Considerations. Journal of Personality and Social Psychology, 51 (6), 1173-1182.

Bhaskar, U., \& Mishra, B. (2017). Exploring Relationship between Learning Organizations Dimensions and Organizational Performance. International Journal of Emerging Markets, (just-accepted), 00-00.

Bing, L.I.U., \& Zhengping, F.U. (2011). Relationship between Strategic Orientation and Organizational Performance in Born Global: A Critical Review. International Journal of Business and Management, 6(3), 109.

Brower, J., \& Rowe, K. (2017). Where the Eyes go, the Body Follows?: Understanding the Impact of Strategic Orientation on Corporate Social Performance. Journal of Business Research, 79, 134-142.

Chahal, H., Chahal, H., Dangwal, R.C., Dangwal, R.C., Raina, S., \& Raina, S. (2016). Marketing Orientation, Strategic Orientation and their Synergistic Impact on Business Performance: A Case of SMEs in Emerging Context (India). Journal of Research in Marketing and Entrepreneurship, 18(1), 27-52. 
Dekoulou, P., \& Trivellas, P. (2015). Measuring the Impact of Learning Organization on Job Satisfaction and Individual Performance in Greek Advertising Sector. Procedia-Social and Behavioral Sciences, 175, 367-375.

Eris, E.D., Neczan, O.,\& Ozmen, T. (2012). The Effect of Market Orientation, Learning Orientation and Innovativeness on Firm Performance: A Research from Turkish Logistics Sector, 5(1), 77-108.

Franczak, J., Weinzimmer, L.,\& Michel, E. (2009). An Empirical Examination of Strategic Orientation and SME Performance. Small Business Institute National Proceedings, 33 (1), 68-77.

Gupta, V.K., \& Gupta, A. (2015).Relationship between Entrepreneurial Orientation and Firm Performance in Large Organizations over Time.Journal of International Entrepreneurship, 13(1), 7-27.

Jansson, J., Nilsson, J., Modig, F., \& HedVall, G. (2017). Commitment to Sustainability in Small and Medium Sized Enterprises: The Influence of Strategic Orientations and Management Values. Business Strategy and the Environment, 26(1), 69-83.

Karajeh, H., \& Maqableh, M. (2014). Security of cloud computing environment. The 23rd IBIMA Conference on Vision 2020: Sustainable Growth, Economic Development, and Global Competitiveness, USA, 2202-2215.

Kateb, M., Swies, R., Obeidat, B., \& Maqableh, M. (2015). An investigation on the critical factors of information system implementation in Jordanian information technology companies. European Journal of Business and Management, 7(36), 11-28.

Kattoua, T., Al-Lozi, M., \& Alrowwad, A. (2016). A review of literature on E-learning systems in higher education. International Journal of Business Management \& Economic Research, 7(5), 754-762.

Khwaldeh, S., Al-Hadid, I., Masa'deh, R., \& Alrowwad, A. (2017). The association between e-services web portals information quality and ICT competence in the Jordanian universities. Asian Social Science, 13(3), 156-169.

Kim, K., Kim, K., Watkins, K.E., Watkins, K.E., Lu, Z., \& Lu, Z. (2017). The Impact of a Learning Organization on Performance: Focusing on Knowledge Performance and Financial Performance. European Journal of Training and Development, 41(2), 177-193.

Malik, P., \& Garg, P. (2017). The Relationship between Learning Culture, Inquiry and Dialogue, Knowledge Sharing Structure and Affective Commitment to Change. Journal of Organizational Change Management, 30(4). 
Marsick, V.J., \& Watkins, K.E. (2003). Demonstrating the Value of an Organization's Learning Culture: The Dimensions of the Learning Organization Questionnaire. Advances in Developing Human Resources, 5(2), 132-151.

Maqableh, M., \& Karajeh, H. (2014). Job scheduling for cloud computing using neural networks. Communications and Network, 6(3), 191-200.

Maqableh, M., Rajab, L., Quteshat, W., Khatib, T., \& Karajeh, H. (2015). The impact of social media networks websites usage on students' academic performance. Communications and Network, 7(4), 159-171.

Masa'deh, R. (2016). The role of knowledge management infrastructure in enhancing job satisfaction at Aqaba five star hotels in Jordan. Communications and Network, 8(4), 219240.

Masa'deh, R., Al-Henzab, J., Tarhini, A., \& Obeidat, B. (2018). The Associations among Market Orientation, Technology Orientation, Entrepreneurial Orientation and Organizational Performance. Benchmarking: An International Journal, 25 (8), 3117-3142.

Masa'deh, R., Gharaibeh, A., Maqableh, M., \& Karajeh, H. (2013a). An empirical study of antecedents and outcomes of knowledge sharing capability in Jordanian telecommunication firms: A structural equation modeling approach. Life Science Journal, 10(4), 2284-2296.

Masa'deh, R., Hunaiti, Z., \& Bani Yaseen, A. (2008). An integrative model linking ITbusiness strategic alignment and firm performance: The mediating role of pursuing innovation and knowledge management strategies. Communications of the International Business Information Management Association (IBIMA) Journal.

Masa'deh, R., Shannak, R., \& Maqableh, M. (2013b). A structural equation modeling approach for determining antecedents and outcomes of students' attitude toward mobile commerce adoption. Life Science Journal, 10(4), 2321-2333.

Mikkawi, B., \& Al-Lozi, M. (2017). The impact of knowledge management infrastructure on academic staff effectiveness: An empirical study at The University of Jordan. Jordan Journal of Business Administration, 13(1), 95-127.

Mu, J., \& Di Benedetto, C. A. (2011). Strategic Orientations and New Product Commercialization: Mediator, Moderator, and Interplay. R\&D Management, 41(4), 337359.

Obeidat, B., Hadidi, A., \& Tarhini, A. (2017a). Factors affecting strategy implementation: a case study of pharmaceutical companies in the Middle East. Review of International Business and Strategy, 27(3), 386-408. 
Obeidat, B., Tarhini, A., \& Aqqad, N. (2017b). The impact of intellectual capital on innovation via the mediating role of knowledge management: A structural equation modeling approach. International Journal of Knowledge Management Studies, 8(3/4), 273-298.

Onyema, E. O. (2014). Effects of Entrepreneurial Orientations on Organizational Learning in a Manufacturing Firm in Nigeria. International Journal of Business Administration, 5(2), 94.

Pokharel, M.P., \&Choi, S.O. (2015). Exploring the Relationships between the Learning Organization and Organizational Performance. Management Research Review, 38(2), 126-148.

Santos-Vijande, M.L., Sanzo-Perez, M.J., Alvarez-Gonzalez, L.I., \& Vazquez-Casielles, R. (2005). Organizational Learning and Market Orientation: Interface and Effects on Performance. Industrial Marketing Management, 34(3), 187-202.

Sarker, S., \&Palit, M. (2015). Strategic Orientation and Performance of Small and Medium Enterprises in Bangladesh. International Journal of Entrepreneurship and Small Business, 24(4), 572-586.

Sekaran, U.,\& Bougie, R. (2013).Research Methods for Business (6th ed.). United Kingdom: John Wiley \& Sons Ltd.

Slater, S. F., \& Narver, J. C. (1995). Market Orientation and the Learning Organization. The Journal of marketing, 63-74.

Sobel, M.E. (1982).Asymptotic Confidence Intervals for Indirect Effects in Structural Equation Models. In S. Sociological methodology 1982 (pp. 290-312). San Francisco: Jossey-Bass.

Song, J.H., Joo, B.K.B., \&Chermack, T.J. (2009). The Dimensions of Learning Organization Questionnaire (DLOQ): A Validation Study in a Korean Context. Human Resource Development Quarterly, 20(1), 43-64.

Stephen, I.A., Oluseye, O.O., \& Abolaji, A.J. (2017). Extending the Knowledge Strategy Concept: Linking Organizational Knowledge with Strategic Orientations. Academy of Strategic Management Journal, 16(3).

Tarhini, A., Alalwan, A., Al-Qirim, N., \& Algharabat, R. (2018). An analysis of the factors influencing the adoption of online shopping. International Journal of Technology Diffusion (IJTD), 9(3), 68-87.

Tarhini, A., Al-Badi, A., Almajali, M., \& Alrabayaah, S. (2017a). Factors influencing employees' intention to use cloud computing. Journal of Management and Strategy, 8(2), 47. 
Tarhini, A., Al-Busaidi, K., Bany Mohammed, A., \& Maqableh, M. (2017b). Factors influencing students' adoption of e-learning: A structural equation modeling approach. Journal of International Education in Business, 10(2), 164-182.

Tarhini, A., Bany Mohammed, A., \& Maqableh, M. (2016). Modeling factors affecting student's usage behaviour of e-learning systems in Lebanon. International Journal of Business and Management, 11(2), 299.

Tarhini, A., Mgbemena, C., \& Trab, MSA. (2015). User adoption of online banking in Nigeria: A qualitative study. Journal of Internet Banking and Commerce, 20(3), 1-8.

Theodosiou, M., Kehagias, J., \& Katsikea, E. (2012). Strategic Orientations, Marketing Capabilities and Firm Performance: An Empirical Investigation in the Context of Frontline Managers in Service Organizations. Industrial Marketing Management, 41(7), 1058-1070.

Tomal, D.R., \& Jones, K.J. (2015). A Comparison of Core Competencies of Women and Men Leaders in the Manufacturing Industry. The Coastal Business Journal, 14(1), 13.

Tseng, S.M., \& Lee, P.S. (2014). The Effect of Knowledge Management Capability and Dynamic Capability on Organizational Performance. Journal of Enterprise Information Management, 27(2), 158-179.

Wahda. (2017). Mediating Effect of Knowledge Management on Organizational Learning Culture in the Context of Organizational Performance. Journal of Management Development, 36(7), 846-858.

Wheelen, T.L., \& Hunger, J.D. (2017). Strategic Management and Business Policy. Pearson, page 55 .

Yassien, E., \& Mufleh, M. (2017). The impact of ERP system's usability on enterprise resource planning project implementation success via the mediating role of user satisfaction. Journal of Management Research, 9(3), 49-71.

Yu, T., \& Chen, C.C. (2012). A Study on the Relationship between Organizational Learning Culture and Organizational Performance in Taiwan's University and College Libraries. Journal of Educational Media \& Library Sciences, 50(2).

Zehir, C., Can, E., \& Karaboga, T. (2015). Linking Entrepreneurial Orientation to Firm Performance: The Role of Differentiation Strategy and Innovation Performance. ProcediaSocial and Behavioral Sciences, 210, 358-367. 